\title{
Emerging Subspecialties in Neurology:
}

\section{Global health}

Section Editor

Michael S.V. Elkind,

MD, MS
Omar K. Siddiqi, MD

Igor J. Koralnik, MD

Masharip Atadzhanov,

$\mathrm{MD}, \mathrm{PhD}, \mathrm{FRCP}$

Gretchen L. Birbeck, MD, MPH, DTMH, FAAN

Correspondence to

Dr. Siddiqi:

osiddiqi@bidmc.harvard.edu

Supplemental data at www.neurology.org
Global health is the study, research, and practice that places a priority on improving health and achieving equity in health for all people worldwide. ${ }^{1}$ In contrast to the public health concerns of a particular country or region, global health looks at populations irrespective of borders. One of the key elements in advancing the field of global health was the establishment of the WHO in 1948. Since its inception, the WHO has helped coordinate global efforts toward eradication of diseases such as smallpox and polio as well as elimination of onchocerciasis. It now assumes responsibility for the International Classification of Diseases. More recently, the field of global health has received considerable attention from world leaders, philanthropists, and academics. In 2009, President Obama introduced his Global Health Initiative that proposed spending $\$ 63$ billion over 6 years to support global health programs specifically targeting areas such as HIV/ AIDS, malaria, tuberculosis, nutrition, and reproductive health. On his first day of work as NIH Director, Francis Collins announced global health as one of his 5 themes of "exceptional opportunity" that would receive special priority during his tenure. $^{2}$ The Fogarty International Center is a branch of the NIH that helps to support global health research for US and foreign researchers, often in resource-limited settings. The research initiatives encompass a diverse range of disciplines within the field of medicine.

NEUROLOGY AND GLOBAL HEALTH There is a common misconception, even among those in the field, that neurology is too specialized for global health and that the most pressing issues are best addressed through more general disciplines such as internal medicine or pediatrics. However, according to the WHO, neurologic disorders account for $11 \%$ of all of the world's premature deaths and years lived with disability. ${ }^{3,4}$ Stroke accounts for approximately $10 \%$ of deaths worldwide with $85 \%$ of stroke occurring in low-income and middle-income countries. ${ }^{5,6}$
Though the field of neurology as it applies to global health in many ways is still in its nascent stages, there is a successful history of coordinated global efforts in addressing neurologic diseases. The directed study of families from Ohio and the shores of Lake Maracaibo, Venezuela, were central to the mapping of the Huntington disease gene. The discovery of human T-lymphotropic virus 1 (HTLV-1) in the United States allowed researchers to prove that tropical spastic paraparesis in the Caribbean and in Japan were the same disease, now called HTLV-1-associated myelopathy.

The need to attract neurologists into the field of global health is further highlighted by the burden of neurologic diseases and the relative lack of neurologic expertise particularly in resource-limited settings. Two-thirds of the neurologic disease burden occurs in the developing world, including $80 \%$ of epilepsy cases. ${ }^{7}$ In one survey, 35 of 50 African nations (70\%) had 4 or fewer neurologists in the country, with 12 nations completely lacking neurologists. ${ }^{8}$ In these settings, the presence of a neurologist is a relatively recent occurrence and most generalists have received their training in almost total absence of neurologic specialty skills. As a result, many neurologic conditions are unrecognized and remain untreated. Furthermore, cognitive dysfunction associated with neurologic diseases undermines compliance with treatment of common medical conditions. Neurologists engaging in global health activities can help build local capacity through training and research so that there is enduring expertise within countries. In addition, neurology global health specialists can advise policymakers on issues related to treatment gaps, drug costs, and public health campaigns as they apply to neurologic illness.

GETTING INVOLVED There are varying levels of engagement for a neurologist to become involved in global health activities. At a training level, a number of neurology residency training programs around

From the Department of Neurology (O.K.S., I.J.K.), Beth Israel Deaconess Medical Center, Boston, MA; Department of Internal Medicine, University of Zambia School of Medicine (O.K.S, M.A.), Lusaka, Zambia; Michigan State University (G.L.B.), East Lansing; and Chikankata Hospital, Epilepsy Care Team (G.L.B.), Mazabuka, Zambia.

Go to Neurology.org for full disclosures. Funding information and disclosures deemed relevant by the authors, if any, are provided at the end of the article. 
the United States have developed relationships with institutions in resource-limited settings where trainees can perform clinical electives. These electives provide valuable opportunities for trainees to gain exposure to uncommon diseases as well as a chance to formulate research questions applicable to a specific setting. In addition, the World Federation of Neurology (WFN) formed the International Working Group of Young Neurologists and Trainees to support international training exchange. Neurologists further along in their careers can perform short stints as visiting professors in underserved regions. The WFN Visiting Professors Program in Zambia has sponsored a number of academic neurologists from all over the world to spend a month in Zambia to provide clinical work and teaching to trainees in Zambia. The Movement Disorder Society has a similar program in under-represented countries. ${ }^{9}$ There are global health opportunities within medical education. In recognition of the heterogeneity in neurologic training across Europe, the European Association of Young Neurologists and Trainees is working toward harmonizing training across the region. ${ }^{10}$ Another potential area of engagement is at the level of a neurologic society. A successful example of this is the Nigeria Florida Neuroscience Partnership with its goal to improve the state of neurologic care and education in Nigeria. The American Academy of Neurology has recently recognized the increasing importance of global health as it applies to neurology with the formation of a Global Health Section (http://www.aan.com/go/ about/sections/global).

CAREER PROSPECTS The possibility also exists to have a career that is fully dedicated to neurology global health activities. There are numerous funding opportunities available to neurologists who are interested in conducting global health research (table e-1 on the Neurology ${ }^{\circledR}$ Web site at www. neurology.org). The success from small research projects can often lead to more substantial funding toward a more comprehensive study. There are several models for an academic neurologist from the United States choosing to focus on global health. An individual can be based full-time at a foreign institution through a funded research project while maintaining an academic affiliation with a medical center in the United States. The advantage to living overseas full-time is that neurologists can embed themselves into a country, helping to improve neurologic services and education from the ground. Another model is spending a significant portion of the year outside the country, engaging in research activities with the help of in-country collaborators. This is most easily done when a reliable research team or local partners are present to carry out activities when the researcher returns home. A final model would be a neurologist based in the United States who makes periodic visits to a particular site in order to supervise research or clinical care. There are a number of academic neurologists from the United States who follow the models outlined above. An alternative approach would be to pursue a position through a public agency such as the NIH, Centers for Disease Control and Prevention, or WHO, all of which have global health programs that include neurologic illness.

DISCUSSION The need for neurology global health specialists continues to grow as the world becomes increasingly interconnected and various neurologic illnesses, once confined to specific regions, now appear in novel settings. With more neurologists participating in global health activities, the specialty will become more easily accessible to those who have an interest in the field but are unclear how to become involved. An increase in funding opportunities would also entice more neurologists into the specialty and help support it as a legitimate career path. It is imperative to bring global health further into the consciousness of the neurology community in order to achieve the specialty's ultimate goal: equity in neurologic care throughout the world.

\section{AUTHOR CONTRIBUTIONS}

O. Siddiqi contributed to the study concept and design of the manuscript. I. Koralnik contributed a critical revision of the manuscript for important intellectual content. M Atadzhanov contributed a critical revision of the manuscript for important intellectual content. G. Birbeck contributed a critical revision of the manuscript for important intellectual content.

\section{STUDY FUNDING}

Supported by National Institutes of Health: Fogarty International Center grant R21 NS073509 and R24 TW0077988; Harvard Center for AIDS Research grant P30 AI060354; and American Academy of Neurology Clinical Research Training Fellowship.

\section{DISCLOSURE}

O. Siddiqi is funded by NIH grant R21 NS073509 and received support from the American Academy of Neurology. I. Koralnik is funded by NIH grants K24 NS060950, R01 NS047029, and R01 NS074995. M. Atadzhanov reports no disclosures. G. Birbeck is funded by NIH grants R01 NS074409, R21 NS073509, R01 NS061693, and R21 NS069228. Go to Neurology.org for full disclosures.

Received June 20, 2012. Accepted in final form October 1, 2012.

\section{REFERENCES}

1. Koplan JP, Bond TC, Merson MH, et al. Towards a common definition of global health. Lancet 2009;373: 1993-1995.

2. Wadman M. Francis Collins: one year at the helm. Nature 2010;466:808-810. 
3. Mathers C, Stevens G, Mascarenhas M. Global Health Risks: Mortality and Burden of Disease Attributable to Selected Major Risks. Geneva: World Health Organization; 2009.

4. Aarli J, Dua T, Janca A, Muscetta A. Neurological Disorders: Public Health Challenges. Geneva: World Health Organization; 2006.

5. Johnston SC, Mendis S, Mathers CD. Global variation in stroke burden and mortality: estimates from monitoring, surveillance, and modeling. Lancet Neurol 2009;8: 345-354.

6. World Health Organization. Mortality Estimates by Cause, Age, and Sex for the Year 2008. Geneva: WHO. Available at: www.who.int/healthinfo/global_burden_disease/en/. Accessed May 29, 2012.

7. Owolabi MO, Bower JH, Ogunniyi A. Mapping Africa's way into prominence in the field of neurology. Arch Neurol. 2007;64:1696-1700.

8. Bower JH, Zenebe G. Neurologic services in the nations of Africa. Neurology 2005;64:412-415.

9. Movement Disorders Society. Visiting Professor Program: 2012. Available at: http://www.movementdisorders.org/ education/visiting/. Accessed June 6, 2012.

10. Struhal W, Sztriha LK, Rejdak K, et al. International Issues: the EAYNT: ten years of unifying European junior neurologists. Neurology 2011;76:e4-e6. 


\title{
Neurology
}

\author{
Emerging Subspecialties in Neurology: Global health \\ Omar K. Siddiqi, Igor J. Koralnik, Masharip Atadzhanov, et al. \\ Neurology 2013;80;e78-e80 \\ DOI 10.1212/WNL.0b013e31828250e9
}

This information is current as of February 18, 2013

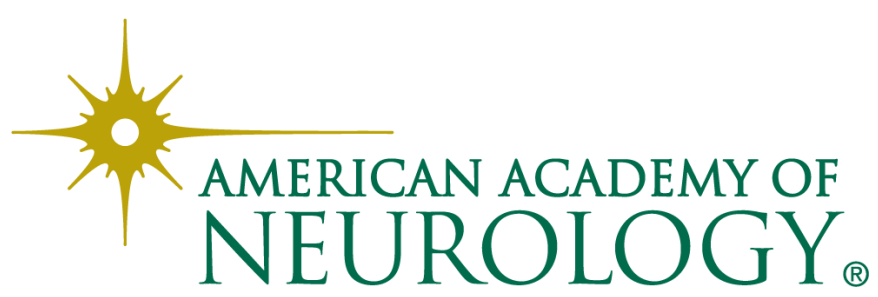




\section{Updated Information \& Services}

\section{Supplementary Material}

\section{References}

Citations

Subspecialty Collections

\section{Permissions \& Licensing}

Reprints including high resolution figures, can be found at: http://n.neurology.org/content/80/8/e78.full

Supplementary material can be found at: http://n.neurology.org/content/suppl/2013/02/17/80.8.e78.DC1

This article cites 6 articles, 2 of which you can access for free at: http://n.neurology.org/content/80/8/e78.full\#ref-list-1

This article has been cited by 3 HighWire-hosted articles: http://n.neurology.org/content/80/8/e78.full\#\#otherarticles

This article, along with others on similar topics, appears in the following collection(s):

\section{All Education}

http://n.neurology.org/cgi/collection/all_education

All Health Services Research

http://n.neurology.org/cgi/collection/all_health_services_research Health policy

http://n.neurology.org/cgi/collection/health_policy

\section{Public health}

http://n.neurology.org/cgi/collection/public_health

\section{Training-international}

http://n.neurology.org/cgi/collection/training_international

Underserved populations

http://n.neurology.org/cgi/collection/underserved_populations

Information about reproducing this article in parts (figures,tables) or in its entirety can be found online at:

http://www.neurology.org/about/about_the_journal\#permissions

Information about ordering reprints can be found online:

http://n.neurology.org/subscribers/advertise

Neurology ${ }^{\circledR}$ is the official journal of the American Academy of Neurology. Published continuously since 1951, it is now a weekly with 48 issues per year. Copyright @ 2013 American Academy of Neurology. All rights reserved. Print ISSN: 0028-3878. Online ISSN: 1526-632X.

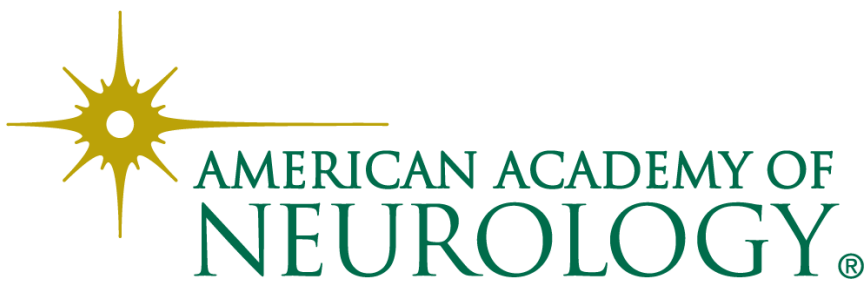

